\title{
Retrospection: The First Hundred Years of North Carolina's Libraries -1945 -
}

\author{
by Elizabeth H. Smith
}

his fourth in a series of articles about North Carolina's libraries begins after several years of rapid expansion and increasing interest in libraries. A bright future for libraries changed quickly in the 1930s when an economic crisis affected library funding. By the end of the decade, libraries had recovered somewhat and shared thousands of dollars in federal funding for public, school, and college libraries that paid for numerous projects such as building repairs, extended hours, and book mending. ${ }^{1}$ Early in the 1940s, however, the country was involved in another war that had positive and negative effects on libraries. Citizens increasingly looked to libraries for information related to the war at a time when libraries were losing personnel to the war. In addition to 1,500 Work's Progress Administration (W.P.A.) employees who had worked in North Carolina libraries as book menders and as assistants in school and public libraries and reading rooms, many trained library staff left their jobs to work in military libraries. ${ }^{2}$

\section{Public Libraries}

The economic crisis had a tremendous impact on public libraries supported by the Library Commission budget, which was reduced from $\$ 27,000$ in 1927-1928 to $\$ 9,288$ in 1933-1934. Salaries were cut 30-50\%, the Library Bulletin was not published for a while, and travel and book funds were cut. Larger public libraries in cities that were in economic crisis received less support than smaller libraries in communities where patrons were closer to their libraries. ${ }^{3}$

The 1933 General Assembly helped library development by passing legislation allowing counties to establish joint library systems that would share staff, books, and facilities. ${ }^{4}$ It also passed legislation requiring certification of public librarians. ${ }^{5}$ The Citizens' Library Movement, which had been started to "improve, strengthen and expand public library service," ${ }^{6}$ supported regional libraries and developed a plan for requesting funds for libraries from the 1937 General Assembly. Unfortunately, legislation for State Aid for Public Libraries in both 1937 and 1939 did not include an appropriation. ${ }^{8}$ In 1939, the NCLA appointed Charles Whedbee of Hertford to the Library Commission Board, and it proved to be a good decision. His visits with every legislator during the fall of 1940 resulted in a 1941 bill for State Aid for Public Libraries that included a $\$ 100,000$ appropriation for both years of the 1941-1943 biennium. ${ }^{9}$ North Carolina was the first southeastern state to appropriate funds for expanded public library service. The 1943 appropriation was increased to $\$ 125,000$, allowing libraries to buy additional books that their readers wanted. ${ }^{10}$

In 1936, two-thirds of the 100 counties had public libraries, and Davidson, Durham, Granville, and Guilford counties had book trucks that made regular trips around the counties. ${ }^{11}$ By 1940, 12 counties owned bookmobiles, several others had remodeled school buses as bookmobiles, and the W.P.A. had 12 demonstration bookmobiles. ${ }^{12}$ In just a few years, bookmobiles became even more important when tires and gasoline were rationed during the war. ${ }^{13}$ Many new library buildings were completed and libraries were opened in various other places such as courthouses, city halls, remodeled church buildings, and other public buildings. Public libraries continued to increase in number during the 1940s as money was raised, funds were donated, and creative locations such as a partitioned section of a railroad station were used to shelve books for the reading public. ${ }^{14}$

The chart below shows the progress public libraries made during the decade of the 1930s.

\section{North Carolina Public Libraries}

$\begin{array}{lcc} & \mathbf{1 9 3 0} & \mathbf{1 9 4 0} \\ \text { Population } & 3,170,276 & 3,561,990 \\ \text { With public library service } & 1,035,276 & 2,001,107\end{array}$


Without public libraries

Volumes in public libraries

Circulation

Income

Income per capita

Counties appropriating $\$ 1,000$ or more

County owned bookmobiles
$2,134,959(62 \%)$

435,142

$2,942,871$

$\$ 199,104$

$\$ \quad .06$

10

3
$1,560,883(43 \%)$

940,877

$5,992,548$

$\$ 328,344$

$\$ \quad .09$

29

$12^{15}$

The Twelfth Report of the North Carolina Library Commission reported the following:

After bank failures of the early 1930s, the Fayetteville library changed from subscription to free and the Sanford library became free to children under the age of 14. Sheppard Memorial Library in Greenville, a gift of Harper G. Sheppard, opened October 17, 1930; Gastonia Public Library, a gift of the Young Men's Christian Association, opened March 27, $1931 .{ }^{16}$

The Thirteenth Report of the North Carolina Library Commission reported the following:

A free library opened at Alta Pass in Mitchell County. The High Point Library moved from the third floor of city hall to the old post office building. The Ayden branch of the Greenville Library was located in a remodeled filling station. The Thomasville branch of the Davidson County Library moved to a larger space on June 20, $1934 .{ }^{17}$ Combined community buildings and libraries opened in Rutherfordton and Tarboro on January 1, 1934. Combined city-county funding made it possible for subscription libraries in Kinston, Sanford, and Lincolnton to offer free service. ${ }^{18}$ New library buildings partially funded with federal funds were under construction in Hillsboro (a memorial to Confederate soldiers), Rowland, and Warrenton (designed to harmonize with the Courthouse and built on the Court House Square). ${ }^{19}$

The Fourteenth Report of the North Carolina Library Commission reported the following:

The Morganton library, a memorial to A.M. Kistler, opened on October 15, 1935. The New Bern Library Association purchased the Stanley home and opened a free public library. In Elizabeth City, the library in the Woman's Club was enlarged to include a children's room. Community building/library combinations were opened in Scotland Neck, Clinton, and Mount Olive. The Sondley Reference Library of 50,000 volumes was opened on the seventh floor of the Asheville city hall. ${ }^{20}$ The Richard B. Harrison Library for Negroes in Raleigh and Wake County opened on November 12, 1935. High Point opened a branch library for Negroes on January 1, 1936. The Davidson County book truck loaded books from the Negro branch and served Negroes of the county. The Negro librarians met at Winston-Salem Teachers College for their third annual meeting April 3-4, 1936. ${ }^{21}$

During the 1940/1942 biennium public libraries contributed to the war effort by purchasing materials related to the world crisis. ${ }^{22}$ The redirection of W.P.A. library workers in 1942 from local public libraries to defense areas and war information centers made it necessary for an increase in local and county support to maintain public library service in many areas. ${ }^{23}$ Library service was established at Fort Bragg and at Camp Davis, but there were not enough books to meet the demand. The American Library Association joined with the American Red Cross and the U.S.O. in organizing the Victory Book Campaign to collect 10 million books for the troops. North Carolinians donated 85,000 books to the cause. ${ }^{24}$

\section{School Libraries}

The North Carolina General Assembly first recognized the school library program in 1901 with funding of $\$ 2,500$ for library books for free public schools. Three decades later new laws changed funding from a matching basis to minimum support for all schools. During the economic crisis of the early 1930s, however, expenditures for school libraries reached a low point only to recover by the middle of the decade and surpass previous highs. Even though the number of books in school libraries tripled between 1925 and 1935, 25\% of children still did not have access to library books. ${ }^{25}$

During this time the image of the library changed from just a collection of books to an organized resource often directed by a teacher-librarian who had completed at least two courses in library technique. ${ }^{26}$ The increase in the number of teacherlibrarians (from 24 in 1930 to 587 by 1940) meant that library collections were better organized and students were better able to find answers they needed. ${ }^{27}$

By 1940, service had become the major component of school library programs and library personnel were expected to know students, books, teachers, and the curriculum, and be able to coordinate all of them into a successful library program. ${ }^{28}$ The 
number of books per student in school libraries (2.4) was still well below the recommended national minimum of five books per student. ${ }^{29}$ With the increased use of libraries, the low number meant books were being used more and thus were quickly wearing out. An average cost of a library book of approximately $\$ 1.25$ meant that it took a large amount of money just to replace those books that were discarded every year. The Library Project of the W.P.A., which supplied labor for book mending, was a tremendous help in making worn-out volumes last for a few more circulations. ${ }^{30}$

School libraries actively participated in the war effort by mounting displays, participating in the salvage effort, hosting first aid classes, and working with the Victory Campaign to collect good quality books for military personnel. ${ }^{31}$ An increase in school library book circulation during the early part of the war was attributed to students working with the war effort; listening to the radio, especially reports about the war; and more work at home for children. During 1943-1944, circulation in school libraries increased by almost one million books. ${ }^{32}$

Many trained school library personnel left for better paying jobs in military libraries, causing a critical shortage by the end of the war. ${ }^{33}$ Collections began to suffer because books had been hard to get and wartime paper and bindings were poor quality. When building supplies became available following the war, library space became a priority in both new construction and renovations. ${ }^{34}$ Students reacted to these improvements in school libraries by increasing their use of books. Between 1931 and 1945, library collections and circulations increased as shown in the chart below:

\section{School Library Collections and Circulations}

$\begin{array}{lrc} & \mathbf{1 9 3 1 - 1 9 3 2} & \mathbf{1 9 4 5 - 1 9 4 6} \\ \text { Library books owned } & 1,395,267 & 3,361,476 \\ \text { Volumes per pupil } & 1.6 & 4.3 \\ & & \\ \text { Circulation } & 3,901,086 & 9,996,218 \\ \text { Average per pupil } & 6.5 & 14.08^{35}\end{array}$

\section{University and College Libraries}

University and college libraries were also affected by the economic crisis during the 1930s. The war had a greater influence on these libraries because decreased enrollments meant less funding.

-Bennett College's new library building opened April 16, 1939. ${ }^{36}$

-The new Davidson College library, which opened in 1942, was a gift from James Parks Grey in honor of his parents. ${ }^{37}$

-Friends of the Library groups had been formed at Duke University, the University of North Carolina, and Wake Forest College. ${ }^{38}$

-Elizabeth City State Teachers College became a four-year degree-granting institution and a library was built in 1939 at a cost of $\$ 88,181$. It was named for G.R. Little in $1955 .{ }^{39}$

-Fire destroyed part of the main building at Greensboro College, which housed the library, in $1941 .{ }^{40}$

-In 1939, the Meredith College library had 22,313 books with a book budget of $\$ 1,673$ and a periodicals budget of $\$ 461.41$

-Four junior college libraries received Carnegie funds for books: Peace Institute, Mars Hill College, Saint Mary's School and Junior College, and Lees-McRae College. ${ }^{42}$

-Salem College and High Point College opened new library buildings in $1937 .{ }^{43}$

-St. Mary's College, which had a library book budget of $\$ 300$ in 1933, received four gifts during the 1930s - one of $\$ 500$ and a Carnegie Corporation gift of $\$ 4,500$ to purchase books and two gifts of books totaling nearly 2,000 volumes. By 1938 , the library would only seat $13 \%$ of the students and the trustees wanted to build a new library with centennial 
campaign funds. They were not able to collect enough money for a new building, so the remodeling project undertaken in 1939 doubled the size of the library and increased seating from 38 to $70 .{ }^{44}$

-Universities and colleges also received significant budget cuts during the Great Depression. Federal programs such as the National Youth Administration (NYA) were very beneficial in helping libraries to continue operating. The University of North Carolina librarian reported that staffing in the General College Library was almost entirely students supported by the NYA. ${ }^{45}$

-A report from 1937-1938 noted that the University of North Carolina library budget was just $21.9 \%$ of that in 1928 1929. Decreasing budgets resulted in plans for cooperation between universities. Inspired by funding of $\$ 25,000$ each from the General Education Board to strengthen their collections in several fields, Duke and UNC began a program of cooperative collection and a daily delivery system between the two libraries. ${ }^{46}$

-The libraries at the University of North Carolina at Chapel Hill and at North Carolina College in Durham were designated as War Information Centers for North Carolina and collected books on defense and the war. ${ }^{47}$

-In 1941, the Wake Forest College library held more than 3,000 books and several thousand pamphlets. ${ }^{48}$

-During the construction project of the 1930s at Western Carolina University, the second floor of the Joyner Building was remodeled as a library and served that purpose until the 1950 s. $^{49}$

One of the most significant events related to North Carolina's libraries during this time was the publication of the first issue of North Carolina Libraries (NCL) in February 1942. It was to be a publication for all types of libraries. The North Carolina Library Commission publication, which had been heavily weighted with public library news, ceased when NCL began publication. Early issues of NCL featured special libraries, school libraries, and Negro libraries. ${ }^{50}$ In 1943 , libraries used $N C L$ to plan their request to the 1945 General Assembly for an increase in State Aid for Public Libraries. ${ }^{11}$ During the next fifteen years, libraries changed as audiovisual materials became an important component of library services. The shortage of trained librarians to staff the growing number of libraries became more critical while the demand for more services continued to increase.

\section{References}

${ }^{1}$ North Carolina Library Commission Thirteenth Report for the Biennium 1932/1934, 9-10.

${ }^{2}$ North Carolina Library Commission Fifteenth Report for the Biennium 1936/1938, 10.

${ }^{3}$ North Carolina Library Commission Thirteenth Report for the Biennium 1932/1934, 5, 2.

${ }^{4}$ Ibid., 3.

${ }^{5}$ North Carolina Library Commission Fourteenth Report for the Biennium 1934/1936, 9.

${ }^{6}$ North Carolina Library Commission Thirteenth Report for the Biennium 1932/1934, 9.

${ }^{7}$ North Carolina Library Commission Fourteenth Report for the Biennium 1934/1936, 10.

${ }^{8}$ North Carolina Library Commission Fifteenth Report for the Biennium 1936/1938, 4; North Carolina Library Commission Sixteenth Report for the Biennium 1938/1940, 7.

${ }^{9}$ North Carolina Library Commission Seventeenth Report for the Biennium 1940/42, 5-6.

${ }^{10}$ North Carolina Library Commission Eighteenth Report for the Biennium 1942/44, 5.

${ }^{11}$ North Carolina Library Commission Fourteenth Report for the Biennium 1934/1936, 4.

${ }^{12}$ North Carolina Library Commission Sixteenth Report for the Biennium 1938/1940, 10.

${ }^{13}$ North Carolina Library Commission Eighteenth Report for the Biennium 1942/44, 5.

${ }^{14}$ North Carolina Library Commission Seventeenth Report for the Biennium 1940/42, 16.

${ }^{15}$ North Carolina Library Commission Sixteenth Report for the Biennium 1938/1940, 16.

${ }^{16}$ North Carolina Library Commission Twelfth Report for the Biennium 1930/1932, 2-3.

${ }^{17}$ North Carolina Library Commission Thirteenth Report for the Biennium 1932/34, 3.

${ }^{18}$ Ibid., 4.

${ }^{19}$ Ibid., 11.

${ }^{20}$ North Carolina Library Commission Fourteenth Report for the Biennium 1934/1936, 9.

${ }^{21}$ Ibid., 10.

${ }^{22}$ North Carolina Library Commission Seventeenth Report for the Biennium 1940/42, 9.

${ }^{23}$ Ibid., 11. 
${ }^{24}$ Ibid., 13

${ }^{25}$ Biennial Report of the Superintendent of Public Instruction of North Carolina, 1933-1934 and 1935-1936, 39.

${ }^{26}$ Biennial Report of the Superintendent of Public Instruction of North Carolina, 1932-1933 and 1933-34, 76.

${ }^{27}$ Biennial Report of the Superintendent of Public Instruction of North Carolina, 1936-1937 and 1937-1938, 99.

${ }^{28}$ Biennial Report of the Superintendent of Public Instruction of North Carolina, 1938-1939 and 1939-1940, 102.

${ }^{29}$ Ibid., 104.

${ }^{30}$ Ibid., 107.

${ }^{31}$ Biennial Report of the Superintendent of Public Instruction of North Carolina, 1940-41 and 1941-1942, 54; North Carolina Libraries 1:1 (February 1942): 3.

${ }^{32}$ Biennial Report of the Superintendent of Public Instruction of North Carolina, 1942-44, 56.

${ }^{33}$ Ibid., 58.

${ }^{34}$ Ibid., 64.

${ }^{35}$ Ibid., 66.

${ }^{36}$ North Carolina Library Commission Sixteenth Report for the Biennium 1938/1940, 14.

${ }^{37}$ North Carolina Library Commission Seventeenth Report for the Biennium 1940/42, 16.

${ }^{38}$ North Carolina Library Commission Fifteenth Report for the Biennium 1936/1938, 12.

${ }^{39}$ Leonard R. Ballou. G.R. Little, Churchman and Chairman. (Elizabeth City, N.C.: Elizabeth City State University, 2000), 58,81 .

${ }^{40}$ North Carolina Library Commission Seventeenth Report for the Biennium 1940/42, 16.

${ }^{41}$ Mary Lynch Johnson. A History of Meredith College. (Raleigh: Meredith College, 1956), 228.

${ }^{42}$ North Carolina Library Commission Fifteenth Report for the Biennium 1936/1938, 10.

${ }^{43}$ Ibid., 11.

${ }^{44}$ Martha Stoops. The Heritage: The Education of Women at St. Mary's College, Raleigh, North Carolina, 1842-1982. (Raleigh: St. Mary's College, 1984), 246-47.

${ }^{45}$ Edward G. Holley. The Library, Philanthropy, Publications, \& UNC's Emergence as a Major American University. (Chapel Hill: Hanes Foundation, 1998), 14.

${ }^{46}$ Ibid., 15.

${ }^{47}$ North Carolina Library Commission Seventeenth Report for the Biennium 1940/42, 10.

${ }^{48}$ George Washington Paschal. History of Wake Forest College, vol. 3. (Wake Forest: Wake Forest College, 1943), 173.

${ }^{49}$ Curtis W. Wood and H. Tyler Blethen. The Illustrated History of Western Carolina University. (Cullowhee: Western Carolina University, 1989), 113, 133.

${ }^{50}$ North Carolina Libraries 2:1 (January 1943): 2-5; 2:3 (May 1943): 2-11; 3:2 (May 1944): 1-10.

${ }^{51}$ North Carolina Libraries 2:2 (March 1943): 5.

\section{Selected Bibliography}

Biennial Reports of the Superintendent of Public Instruction of North Carolina..., 1932-1933 and 1933-1934; 1934-1935 and 1935-1936; 1936-1937 and 1937-1938; 1938-39 and 1939-40; 1940-41 and 1941-42; 1942-44; 1944-46. Raleigh, Department of Public Instruction.

Ballou, Leonard R. G.R. Little, Churchman and Chairman. Elizabeth City, N.C.: Elizabeth City State University, 2000.

Holley, Edward G. The Library. Philanthropy, Publications, \& UNC's Emergence as a Major American University. Chapel Hill: Hanes Foundation, 1998.

Johnson, Mary Lynch. A History of Meredith College. Raleigh: Meredith College, 1956.

North Carolina Libraries. 2:1 (January 1943): 2-5; 2:3 (May 1943): 2-11; 3:2 (May 1944): 1-10.

North Carolina Library Commission Reports. 1930-1932; 1932/1934; 1934/1936; 1936-1938; 1938-1940; 1940/42; 1942 1944.

Paschal, George Washington. History of Wake Forest College. Wake Forest: Wake Forest College, 1943.

Stoops, Martha. The Heritage: The Education of Women at St. Mary's College, Raleigh, North Carolina, 1842-1982. Raleigh: St. Mary's College, 1984.

Wood, Curtis W., and H. Tyler Blethen. The Illustrated History of Western Carolina University. Cullowhee: Western Carolina University, 1989. 